\title{
Cubagua's Pearl-Oyster Beds: The First Depletion of a Natural Resource Caused by Europeans in the American Continent
}

\author{
Aldemaro Romero, Susanna Chilbert, \& M.G. Eisenhart
}

\section{Introduction}

There is an increasing interest in approaching conservation biology from a historical perspective. Calls for understanding the relationship between both disciplines have been made (C. Meine 1999). This interest has centered on the ecological role played by humans when occupying new areas (P. Coates 1998; I. Simmons 1993). Numerous studies have suggested that mass species extinction is one of the most important environmental impacts by humans when expanding their range. This is caused by either exploitation (the "overkill" model, P. Martin 1973, 1990) and/or habitat modification (J. McCann 1999a,b). These mass species extinctions occurring during recent human history have been called neoextinctions (also Holocene, historical, contemporary, or present-day extinctions) (J. Carlton 1993). These phenomena have been documented for many taxa in many parts of the world (C. Humphries and C. Fisher 1994). ${ }^{1}$

The exact mechanisms of how those extinctions occur are not very well understood (D. Forester and G. Machlis 1996; S. Pimm 1996; D. Webster and G. Webster 1984). Since most neoextinctions can be attributed to humans, the study of the interactions between the environment and human social organization and behavior, can help us better understand mechanisms leading toward neoextinctions. This understanding, in turn, could be used in the establishment of conservation policies, particularly in developing nations where there are still large human populations living in rural areas and/or still practicing semiindigenous modes of living.

What we can learn from studying neoextinctions also has far-reaching implications not only in conservation biology but also in the social sciences and the humanities. One practical example has been the rejection of the "Ecologically Noble Savage" hypothesis according to which native peoples have been portrayed as natural conservationists, living in "harmony" with their environment and practicing hunting in ways that would increase the sustainability of their long-term harvest (M. Alvard 1993, 1994, 1995; D. Buege 1996;

1. Specific examples include marine invertebrates (J. Carlton 1993), birds (S. Olson and H. James 1982; S. Pimm et al. 1994), mammals (A. Stuart 1991), and marsupials (D. Choquenot and D. Bowman 1998). Geographical analyses have included the Mediterranean basin (M. Stiner et al. 1999), Papua New Guinea (D. Steadman et al. 1999), Australia (G. Miller et al. 1999; J. O'Connell and J. Allen 1998), the Pacific Islands (S. Pimm et al. 1995), Hawaii (S. Olson and H. James 1982), Guam (T. Fritts and J. Rodda 1998; G. Rodda et al. 1997), the American continent (P. Stahl 1996), North America (P. Martin and C. Szuter 1999), Puerto Rico (A. Brash 1987), and Patagonia (V. Markgraf 1985). 
T. Headland 1997; H. Kallendorf 1995; K. Redford 1990). Another has been the rewriting of history taking the environmental background deeply into consideration (e.g., J. Diamond 1998; B. Pastor Bodmer 1992; C. Ponting 1991; K. Sale 1991; J. Simon 1997). Thus, neoextinctions provide an excellent subject for interdisciplinary environmental studies.

Most of the evidence presented to support conservation biology studies from a historical perspective, however, has been indirect and based on archeological and paleontological data that provide little, if any, understanding of the historical (social, political, economic) and ecological factors involved in such extinctions. Even less known are specific instances of impacts by humans who arrive into new environments inhabited by other humans whose economic and social structures are widely different.

The arrival of Europeans to the American continent offers a good opportunity to analyze neoextinctions. Post-Columbian extinctions are not only more recent but also much better documented from a historical perspective, providing us with the opportunity to understand how social and ecological factors interplayed. In this paper, we describe what we believe is the first case of a natural resource depletion caused by Europeans in the American continent: the pearl-oyster (Pinctada radiata) beds around the island of Cubagua, off the coast of what is today Venezuela. We characterize the historical, economic, social, and political circumstances that led to this depletion and establish the connections between those factors and the natural history of the resource that was depleted. We also use this information to make a case for a perfect example of an unsustainable use of a resource leading toward its local and rapid depletion and the effect of resource overexploitation on native people.

\section{The Geographical Background}

Coche, Cubagua, and Margarita are three major islands off the eastern coast of Venezuela. They are grouped politically as part of the state of Nueva Esparta. They are only about 10, 17, and $25 \mathrm{~km}$, respectively, from the Peninsula of Araya on the mainland of Venezuela. The island of Cubagua is situated 9 kilometers south of the coast of Margarita (R. Willis 1976) (Fig. 1).

Cubagua is an island of subeliptic shape with a total area of $22.438 \mathrm{~km} 2$. It is underlain by a thick deposit of soft sandy fossiliferous shales and clays ranging from Eocene to Miocene in age. This is capped by a an eight-meter thick layer of sandy reef limestone or marl of Pleistocene age (Anonymous 1970:179-181; H. Kugler 1957). It has a cuesta-like form with the largest edge to the north and gently, southward-dipping strata (5-10 degrees); it is an asymmetrical anticline with an east-west striking fault paralleling the north side of the island. Thus, most of the island coast line is lined with cliffs. On the south the cliffs are between five and seven meters high, and those on the north range between 20 and $25 \mathrm{~m}$. The entire island has a rather flat landscape with altitudes not higher than $32 \mathrm{~m}$ above sea level.

The exception to this general landscape is on the northeast corner of the island where there is a rectangular-shaped lowland about two and a half kilometers long and two kilometers wide, known as La Cabecera de Cubagua (Fig. 2). About $800 \mathrm{~m}$ north of this lowland and attached to it by a sand bar is a small triangular piece of lowland. Most of the events narrated below took place in the town of Nueva Cñdiz which is located on this lowland.

Cubagua's climate is heavily influenced by predominant trade winds. Surface temperatures are generally above $25^{\circ} \mathrm{C}$ with little annual variations. Average annual 
precipitation is $250 \mathrm{~mm}$, classifying it as a dry desert. The island is very well drained because of its sandy and clay soil over mostly limestone bedrock (M. Helmer 1962). The island's only freshwater is found in small underground reservoirs. Plant species are sparse and typically xerophytic: they include a number of Cactaceae such as cardón de dato (Ritterocereus griseus), buche, melón de cerro, sabana o monte (Melocactus caesius), guamacho (Pereskia guamacho), and tuna (Opuntia tuna), as well as a few legumes including members of the family Fabaceae such as yaque, cuj, or honey mesquite (Prosopis juliflora), guatapamare or dividivi (Caesalpinia coriaria), poorman's friend (Stylosanthes viscosa), and the Euphorbiaceae sangre drago (Croton flavens) (J. Johnston 1909; B. Olivo Chac, n 1989).

\section{The Historical Background}

The first human occupation of Cubagua has been dated to 4187 BP (2325 BC) - 80; it is represented by shell, fish bone, and echinoderm middens deposited by peoples of the Meso-Indian Period (5000-1000 BC) who were coastal and island fishers (R. Cooke 1998; I. Rouse and J. Cruxent 1963:39). They probably traveled from the mainland to the islands by means of rafts (I. Rouse and J. Cruxent 1963:45-46) and may have replaced the big game hunting culture of the Paleo-Indian on the mainland as a response to the extinction of the large game animals. Some exploitation of marine mammals by these earlier cultures also took place (A. Romero, A. Agudo and S. Green 1997).

Between the earliest known occupation until the arrival of the Europeans, a number of different cultures occupied the coastal areas of what is today eastern Venezuela. The chronology of those cultures have been summarized in G. Willey (1971, 2:363). By the time of the Spanish arrival, the people in the area were linguistically Caribans of Venezuela (G. Willey 1971, 2:13).

All archeological evidence suggests that these first humans never settled permanently in Cubagua,but that they visited the islands with the purpose to exploit the rich oyster beds both for food as well as pearls for ornamentation. The lack of fresh water and significant terrestrial vegetation made permanent settlement difficult. To this day, only a few fishers temporarily settle on the island (R. Willis 1976: 8-11).

What follows is a synthesis of the conquest and colonial history of this island based on contemporary witnesses (G. Benzoni 1565; J. Castellanos 1589/1857; B. Las Casas 1552; F. López de Gómara 1554; G. Oviedo y Valdez 1535), modern studies of documentation of that time (M. Helmer 1962; G. Morón 1954; E. Otte 1961), and the archaeological findings from these islands (summarized in R. Willis 1976).

The discovery and exploitation of the oyster beds in Cubagua by the Spaniards can be divided into four stages:

\section{Discovery and First European Exploitations (1498-1502)}

Christopher Columbus was the first European to discover the economic potential of Cubagua during his Third Voyage in July and August 1498. Then, he traded pearls for hawk's bells, beads and sugar with the local natives who approached his ship while exploring the area of the Paria peninsula in what is today the eastern coast of Venezuela. He obtained more than six marks (about 1.4 kilos) of pearls. These natives told Columbus where he could find the oysters' beds, but due to the pressing problems in Hispaniola (his final destination), the spoiling cargo, and his deteriorating health, he elected to continue to Hispaniola. He planned to send his brother Bartolomé El Adelantado to continue the 
exploration of the coast later but he had to abandon any plans to further explore the oyster beds when he and his brother were arrested as a result of political intrigues (C. Sauer 1966:97).

Columbus' political enemies took advantage of the fact that he had never set foot on the Paria Peninsula (which in legalistic terms meant that he had never taken possession of the land). They issued capitulaciones (contracts) allowing others to explore what Columbus discovered. Thus, at least two voyages to the Paria peninsula were undertaken in 1499: one by Alonso de Hojeda (or Ojeda) and the other by Peralonso (or Pedro Alonso) Niño. They sailed in the latter part of May, a few days apart. The trip by Niño was financed by the brothers Luis and Cristóbal Guerra, with the latter as captain, and a crew of 33 men. They were forbidden to navigate within 50 leagues $(275 \mathrm{~km})$ of where Columbus had been, something they ignored altogether. Sailing directly to the Gulf of Paria, they followed the peninsula of Araya west until stopping in the strait between Margarita and the mainland, northwest of present Cumaná, to cut a load of brazilwood (Caesalpina echinata), a valuable commodity in early times of the American conquest ( $R$. Defilipps 1998). Here they encountered natives who were quite willing to trade their pearls. For the next six or seven months Niño and Guerra proceeded westward along the mainland exploring and trading for pearls (C. Sauer 1966:106-108).

The richest pearl-oyster beds areas were east to Cubagua and Coche, east and southeast of Margarita, and northwest of the Araya peninsula (Fig. 2). This section of the coastline was soon to become known as the Pearls' Coast ("Costa de las Perlas"), so named by Luis Guerra in a letter to Alvaro de Portugal dated September 28, 1500 (Morón 1954: 145). At the end of the expedition, Niño and Guerra had accumulated at least $96 \mathrm{lb}$ $(44.16 \mathrm{~kg})$ of pearls "some as large as hazelnuts, very clear and beautiful, though poorly strung"(Martyr I(8)). This was the first truly profitable voyage to the West Indies. On the return voyage early in 1501, Niño and his men quarreled over the division of the pearls. Upon reaching Spain, Niño's crew accused him of secreting pearls in order to cheat the king out of taxes, and of having violated his license by trading at Cumanñ and other places visited by Columbus. Because the Spanish Crown had declared the pearl trade a royal monopoly, Niño and the Guerra brothers were arrested, and their pearls and vessels were confiscated.

After a brief time in jail, the Guerra brothers and other adventurers organized expeditions from 1499 until the fall of 1502. They explored the coast between what is today Suriname and Panamñ, engaging not only in pearl trading but also cutting brazilwood and hunting for slaves. Luis Guerra's second expedition, which he himself accompanied, yielded nearly a costal (sack-full - 46 kilos) of pearls, but their vessel was wrecked on the return to Spain (S. Mosk 1938). It is quite possible that many more Spaniards from Hispaniola, Borinquen (Puerto Rico), or Spain, ventured into Cubagua during those years; however, they did so without permission and thus left no historical records.

\section{First European Settlements (1502-1508)}

The first European settlements in Cubagua were rancher,as, simple huts of clay and straw. These rancher, as were established by adventurers and unauthorized travelers from Santo Domingo and even by a few British subjects (I. Rouse and J. Cruxent 1963:131) who located the major concentration of pearl oysters off Cubagua. They did not permanently occupy Cubagua but camped from three to four months a year while trading. 
Given the increasing demand for pearls and the potential tax benefits to the Spanish Crown in 1504, Ferdinand, King of Spain, ordered his governor at Hispaniola, Nicolás de Ovando, to build a fortress in the Pearls' Coast in order to provide protection and a site for pearl commerce. The next year Ovando organized an expedition to scout for the best place for the fortress and to establish commercial relations with the natives. Ovando returned to Spain with 39 marks (about 9 kilos) of pearls. His pearls were not very large, rarely exceeding five carats. Ovando wrote a report to the King in 1509 in which he recommended not to spend too much time, money and effort trying to build a city on that island due to the lack of freshwater. He further explained that having developed good relations with the natives (some of which were already being used to dive for pearls), there was no need for further conquest efforts since trade could continue for many years. He also recommended that visits to the island be prohibited to those extracting pearls without paying taxes. Although the King acknowledged and approved those recommendations for the "Pearl Island," they were never implemented. Even worse, Ferdinand later encouraged others to settle on the island (C. Sauer 1966:190-191).

Early on, the trade went well. Apparently the Spaniards tried to keep good relations with the Guayquer, Indians of Margarita in order to avoid the mistakes made in Hispaniola where the Spaniards both alienated and eradicated the local labor force. Natives were happy to trade pearlsfor wine, linen shirts, wheat bread, firearms and other European goods. Friendly (Simpñticos) settlers were given a native woman as a wife or concubine, and the Spaniards made themselves valuable against the Carib attacks and the incursions of other Spaniards from the American mainland who were trying to enslave the Guayquer,s.

This idyllic (from the Spaniards' viewpoint) relationship was short-lived. Tensions soon arose. As more Spaniards poured into these islands, the natives started to demand more for the pearls and insisted that the Europeans had to go to Margarita Island to haggle for them. Since the Guayquerís were more than satisfied with the initial level of trade, they showed little interest in intensifying pearl extraction. This irritated the ever growing number of Spaniards who became convinced that the only solution to satisfy their demand for pearls was to enslave the natives. Any native resisting Spanish sovereignty could be enslaved; the same could be said of any native labeled as "cannibal"(P. Hulme 1986), so excuses for enslaving natives were easy to come up with. Although natives could not officially be sold or bought, they could be "allotted" to resident Spaniards, for whom they were obliged to work in return for being catechized in the Faith, a system called Encomienda (L. Simpson 1970). During the first 50 years of its existence, the Encomienda was largely viewed by the Spaniards as a subterfuge for slavery and it was only after half a century of lobbying by reformers such as Las Casas and the intervention of the Crown, that the system was stripped of its unrestricted privilege of using the services of the Indians at will and was transformed into a benevolent paternalism (L. Simpson 1950: xiii; for further discussion on this topic see W. Sherman 1979:85-128), distinguishing it, thus, from actual slavery. Our research has not yielded any evidence that the system of Encomienda was ever implemented by the Spaniards in Cubagua and that the use of natives was under a regime of slavery. This is understandable because by the time these reforms were implemented, Cubagua had been abandoned by the Spaniards.

This transition from peaceful trade to armed extortion or raiding was not difficult for the Spaniards who had practiced both on the West Coast of Africa and the Atlantic islands since the 1300's and received the same name: rescate (barter). It is also not surprising that the Spaniards were not particularly interested in placing permanent colonies where they 
landed. Their tradition in Africa and in the Atlantic islands had always been to build, only, trading posts or small forts at especially promising spots (J. Kicza 1992). Pearls had to be extracted by diving. Since most Spaniards did not even know how to swim, access and control of indigenous workers quickly became primary concerns.

\section{Large Scale Exploitation (1508-1520)}

As Spain's demand for pearls kept increasing, a more substantial labor force was needed. This led to the introduction of natives as slaves from many surrounding islands, including Trinidad, and the Venezuelan mainland coast. The first document which recorded the use of native slaves as pearl divers is dated 1509, although it is believed that they had been in use for several years prior to that (R. Willis 1976). As early as 1508, large numbers of Lucayan Indians from the Bahamas were taken by force to Cubagua (D. Watts 1990:109). Lucayan Indians were especially prized due to their swimming skills and deep diving abilities (they could dive 30 meters or more), skills they had developed through the aboriginal practice of diving for conchs (Strombus spp.). The average pearl bed was at about 13 meters and the deepest one at about 22 meters. Lucayans were easily enslaved. Prices for them reached as high as 150 gold pesos (ducats) a person (S. Mosk 1938: 394). By 1518 the Bahamas had been completely depopulated of Lucayos from a original population believed to be 60,000 (P. Muilenburg 1991).

Africans were also imported and taken to Cubagua to toil in the pearl fisheries. It is possible that a deficient supply of natives and the very bad relations generated by slaving practices led to significant importations of African slaves. Relations between Spaniards and native Americans had deteriorated so much that a Royal decree of 1558 prohibited the use of natives and stated that only Africans should be used in pearl fishing (P. Galtsoff 1950).

By all accounts, the treatment of the native pearl divers was harsh. Once enslaved, they were marked in the face and on the arms by a hot iron with a letter of $\mathrm{C}$ (whose meaning we have not been able to verify but may have been a mark for Cubagua). They were quickly forced to dive for pearls. There were six divers per boat, sitting two by two. One of each pair would dive into the waters to collect oysters, while the others, attached to the diver by a rope, remained in the boat in order to pull the diver to the surface after about a minute (M. Helmer 1962). Each diver was equipped with a small pouch fastened to his waist or neck in which he placed oysters as he removed them from the bottom. After each dive, the man emptied his net full of oysters which were spread on the boat bottom. The heat caused the oysters to open. If diving in deep water, it was customary for the diver to weigh himself down with two heavy stones, enabling him to reach the bottom faster and remain there longer while expending less energy. Natives were allowed little rest time between dives, and if they delayed too long, the overseer threw them off the boat and whipped them until they obeyed (B. Las Casas 1552). At night the pearl divers were chained so they could not escape. Sharks are said to have killed many divers (G. Morón 1954: 153) while hemorrhages produced by water pressure and intestinal disorders caused by diving in cold water also took their toll (B. Las Casas 1552).

At the end of the day (they dove from sunrise to sunset) the entire catch was taken ashore and stored until enough oysters had accumulated, at which time they were examined and culled for pearls (G. Oviedo y Valdez 1535:607-8). One of these boats would in two or three weeks time harvest some 35,000 oysters (A. Humboldt 1799, $1: 357)$. 
Probably because of the short-time period of contact, rapid turnover of indigenous labor, and/or the great social divide created by the master-slave relationship, there was very little, if any, cross-cultural influence between the Spaniards and the natives. Archeological evidence indicates that the Spanish pottery was an almost pure sample of late Medieval Iberian culture of wealthy Spaniards, whereas the native ceramic was crude and simple (R. Willis 1976: ix).

From 1509 on, the Spanish authorities tried to stimulate the establishment of permanent settlements in Cubagua. Because the monopoly could not be enforced, the Spanish government opened up the pearl trade. Initially, Spaniards were required to get a license and pay 50 percent of the proceeds in taxes. Since this did not stimulate the establishment of a permanent settlement in Cubagua, that tax was reduced to 20 percent (el quinto) of the gross production. The profits of the pearl commerce were tremendous, but a lack of water, wood, and construction materials prevented the Spanish from establishing long term residency. The king tried to encourage a permanent settlement in 1512 by asking the Dominicans to settle off the coast of Cumaná, where the Manzanares River could provide fresh water to the colonists in Cubagua. Only two friars arrived in 1513. They were killed by natives in 1515 as a reprisal against other Spaniards for their enslavement practices. In 1516 six Dominicans and six Franciscans went to the coast, establishing missions at Cumaná and P,ritu. Another mission was built in Chichirivichi the following year as part of Bartolomé de las Casas's plan to colonize the entire Venezuelan coast from Paria to Cabo de la Vela using peaceful persuasion instead of force to deal with the natives. Given the increasing hostility of the natives, the trade of pearls for wine and firearms was prohibited in 1516 (E. Otte 1961: xxii).

Charles V became King of Spain in 1519. The demand for pearls intensified due, in part, to the increased desire for luxury in the Court. By that time, Cubagua had become a true wild mining "frontier" land with a resident population of nearly 300. Drinking, gambling, murder, adultery, and rape of native women were common. Antonio Flores, the man sent by the Spanish government to establish order and protect the natives, grossly abused his authority, and enriched himself in the pearl and slave trade. He favored his cronies and punished his enemies with imprisonment, whippings, and confiscation of property. He alienated the Margarita Guayquerís by requiring them to sell their pearls on Cubagua on his own terms. To deal with unrest, he seized two caciques (chieftains), summarily hanged the elder one, strapped the other, still a minor, to the muzzle of a cannon and blew his head off, throwing his body to the dogs.

These excesses led, in 1520, to another rebellion. Natives ambushed a notorious slaver and massacred him and his men. They burned the missions on the mainland and killed all of the friars. The crew of a newly-arrived caravel came ashore and was axed. The natives jumped into the ship's boat and headed out for the caravel. The two crewmen left aboard barely escaped to Cubagua where they told the story. Eight days later another caravel, whose crew was unaware of the recent developments, came to the coast. The natives came aboard, ate and drank and invited the Spaniards to come ashore. Once they had the Spaniards in their power, the natives killed 23 men (P. Muilenburg 1991). The captain and four of his crew escaped and told the story in Hispaniola. The natives also poisoned the water springs in Margarita. Thus, in 1520, with hostile locals everywhere and the inability to get freshwater in the vicinity, Flores seized 200 Margarita natives who were expert divers (and, thus, a priced commodity), crammed them into four caravels, and went to Hispaniola with the rest of the Spaniards. After that, the natives set the rancher,as of Cubagua ablaze (J. Simon Velñquez 1956:50). 
In 1521 the government in Santo Domingo sent a punitive expedition composed of six ships under Captain Gonzalo de Ocampo to crush the rebellion, which he did with a vengeance (E. Otte 1961: xxv). Thus, open hostilities between Europeans and natives continued.

\section{Rise and Fall of Nueva Cñdiz (1523-1545)}

The Spaniards did not control the "Pearls' Coast" politically and militarily until they built a fortress at Cumanñ in 1523 which brought the natives under control and ushered in the fourth and most productive phase in the occupation of Cubagua.

From now on, Nueva Cñdiz reached its economic splendor. Stones were brought from the Araya peninsula and permanent brick buildings were erected. Along with the construction of masonry houses, public buildings were also raised, the most impressive being a Franciscan monastery displaying elaborately carved stone gargoyles imported either from the mainland or Spain (I. Rouse and J. Cruxent 1963:136). In 1527 Nueva Cñdiz was politically incorporated, becoming the first European city in South America, an act ratified by the King of Spain in 1528. It was an independent administrative unit from Hispaniola that reported directly to Spain. The town held jurisdiction over Margarita and the Cumanñ coast. A mayor was elected annually by the Cabildo (City Council).

By 1527 there were 223 Europeans and 700 natives on Cubagua. The first pirate incursion (French) into Cubagua's waters took place that year (E. Otte 1961: xxxi). In 1528 another oyster bank was discovered in Coche (G. Morón 1954: 181), and between 1530 and 1535 fisheries were being exploited to the maximum while supporting a total population of between 1,000 and 1,500. Because of the increased need to feed the local population, by 1529 some engaged in the salt-fish industry (G. Morón 1954: 192).

In 1528 the Emperor authorized the use of dredges to an associate with whom he was to share one third of the benefits. The citizens complained before His Majesty because they believed that this practice would severely deplete the oyster beds and as results of those complaints the use of dredges was authorized only beyond 6 fathoms $(10.02 \mathrm{~m})$. Contemporary documents note the first signs of exhaustion of the pearl oysters by that year (M. Helmer 1962; E. Otte 1977: 34). The Spaniards used more sophisticated dredges and even pressurized diving suits for pearl fishing in California in the early Seventeenth century (P. Hernñndez Aparicio 1976).

By 1531 the city had 1,000 inhabitants (G. Morón 1954, p. 151) and the signs of depletion in the pearl-oyster beds became more acute. The Spaniards began to place limits on boat size and on the number of divers per boat. The number of hours the pearl fishers were allowed to dive was restricted to four per day, at a depth not to exceed 8 fathoms $(13.36 \mathrm{~m})$. These quotas, however, were only applied to certain beds and there is no evidence that these new rules were ever enforced (P. Galtsoff 1950; M. Helmer 1962). Pearl output suggests that this attempt at conservation did little to delay the exhaustion of the pearls.

By 1533 a six-month moratorium was established after which there was a rotation of exploitation between the three islands: four months at Cubagua, three months at Coche, and two months at Margarita. By 1535 oysters were found only at greater depths than before. That year the Spaniards and their slaves started to abandon Cubagua and moved to Margarita; most would end up on what is today the Colombian coast, in Cabo de La Vela and Rio Hacha off the Guajira peninsula, where vast oyster-pearl beds had been discovered earlier (M. Luengo Muñoz 1949). By 1536 the moratorium was extended from January to September (E. Otte 1977: 35). In 1537 the Crown heard that no pearls had been 
obtained in a year and a half. As the fisheries were being depleted, the town suffered an increasing number of attacks by pirates who had heard of the riches of Cubagua, and who took advantage of the fact that the mainland fortress of Cumanñ had been destroyed by an earthquake in 1530. The decline of the pearl production resulted in the accumulation of debt on the island; the Spanish could no longer successfully finance the colony (M. Helmer 1962). By 1537, only one pearl fisher per boat was allowed and in 1539 there were only between 10 and 50 people left on the island. Some of them may have been involved in selling oil found in the eastern part of Cubagua for use as sealant in ships and for medicinal purposes (G. Morón 1954: 193). There are documents dating back to 1536 and 1539 in which the Queen requested oil (azeite petrolio) from Cubagua because of its alleged curative properties against gout (J. Tello 1966). In 1541 what may have been a hurricane (P. Vila 1948) destroyed the remaining buildings, and an attack by French corsairs in 1543 forced the remaining Spaniards to leafe for Margarita.

There were some attempts to revive the pearl fisheries at Cubagua. Writing to the King in 1602, a royal official at Margarita says that Africans from Guinea were brought in large numbers to the island, where they sold for 180 pesos a piece. Slave dealers had found the traffic in African divers quite profitable; payments for the slaves were made in pearls. If the slaves were sold in Spain, this trade yielded an additional 12 percent profit. In 1621, there were only 130 African divers left at Margarita, and it was recommended that 300 be imported in order to rebuild the pearl fishing industry (S. Mosk 1938).

There are signs of a temporary seventeenth century Spanish settlement, referred to as Obispo, on the southeastern shore of Cubagua, about $2.5 \mathrm{~km}$ from the site of Nueva Cádiz. No masonry structure existed; the dwellings probably resembled the thatched rancher, as erected during the initial stages of settlement at Nueva Cádiz. Analysis of the majolica shreds collected at the site indicate a brief occupation at about 1639 (J. Goggin 1968:43). This correlates with the failure of all attempts to restore the fisheries of the Pearls' Coast after 1600 (R. Willis 1976: 25). Some pearl-fishing still took place in the eighteenth and nineteenth centuries in Cubagua, Coche, and Margarita, but always as small scale operations (H. Quiévreux 1900). By the 1960's, 96\% of the oyster-pearl banks were found to be completely or almost completely decimated and the turkey-wing mussel, Arca zebra, had ecologically replaced Pinctada radiata (J. Salaya and L. Salazar 1972). Cubagua was never permanently inhabited again.

\section{The Economic Background and Impact}

Pearls have been a priced commodity throughout history among all cultures that have had access to them. That was particularly true at the time of Columbus' arrival to the American continent (S. Bernabeu 1995; C. de Silva 1978). Trade records as well as paintings and engravings of the fifteenth and sixteenth centuries show that pearls were in great demand and used in abundance by people of rank and fortune (G. Kunz and C. Stevenson 1908). Until 1530 the value of pearls shipped from America to Europe averaged annually 800,000 piasters (more than one-third of all the yearly production of the mines in America). Before the establishment of Mexican and Peruvian mines, pearl exports from the American continent exceeded the value of all other exports combined (G. Kunz and C. Stevenson 1908:23).

Data on the king's revenue from pearls are found in the accounts of shipments made to the Casa de Contratación by the Royal treasury officials at Española. In one month (January 1529), more than 1500 marks (345 kilos) of pearls were obtained from the oyster beds of the island of Cochealone (R. Willis 1976: 22). On January 24, 1533, for example, 
the treasurer turned over to the captain of the vessel Trinidad several boxes of pearls which he had received from the royal officials in Cubagua. One box contained 90 pearls, many of large size; the other boxes each held more than 10 marks ( 2.3 kilos) of rough pearls. The Saint Nicolás, sailing for Spain in June 1533, carried over 200 marks (46 kilos) of pearls, ranging from common to fine. Two boxes of pearls from Cubagua were put into the hands of the captain of the Santa María de Begonia in July 1534; in one of those boxes were 200 marks (46 kilos) of pearls, mostly "common:" while the other contained 1000 small pearls. A shipment of June 3, 1535, included 140 marks (32.2 kilos) of pearls. In June 1536, shipments were sent on two vessels; one carried 100 marks (23 kilos) of common pearls, the other 93 marks (21.39 kilos). In 1538, the squadron of Blasco Nuñez Vela transported pearls worth 208 ducats for the King, while that of Martín Alonso in 1543 carried gems valued at 9000 ducats. The largest of the pearls in the last lot, however, came from Panamá. Those from the Caribbean coast were smaller, weighing at most from 2 to 5 carats, but were found in greater quantities (C. Haring 1964: 165; S. Mosk 1938).

The Spanish set out to harvest the pearls in the most profitable manner as fast as possible. To this end, they used the cheapest slave labor available as pearl divers. Native slaves could be inexpensively procured from other Caribbean islands and the Venezuelan mainland. The importation of African slaves from across the Atlantic Ocean was too costly (M. Helmer 1962) and was not implemented until after the local labor force became to scarce and difficult to obtain. Thus, Cubagua became a clear case of commercial capitalism built up on slavery and monopoly as described for other parts of the Caribbean in later years by E. Williams (1944[1994]).

The pearls harvested from the "Pearls' Coast" were sent back to Spain and used in clothes and jewelry for the nobility, and in ornamentation for the church. Most of them were traded to other nations for manufactured goods. The Spanish relied so heavily on these treasures that they were left with a broken economy once the supply of riches from the Americas had been depleted (M. Helmer 1962). Since Spain had traded its new wealth to other countries, it was left with practically no benefit from the pearls and gold into which it had invested so much time and effort.

The Spanish on the island were encouraged by the great output of pearls to live a luxurious (by local standards) lifestyle. They carelessly maintained this life of luxury as the yield of pearls diminished (M. Helmer 1962). As expected, lack of local resources and rapid, extraordinary wealth encouraged price inflation of essential goods. Prices for products in Cubagua were about twice that of goods in Santo Domingo (E. Otte 1977:298). This resulted in an insurmountable debt (R. Willis 1976).

The economics of Cubagua were unsustainable. Since the island lacked essential natural resources (water, wood, diversified sources of food, construction material, etc.), everything had to be imported. Food came from oysters, turtles, fish, and wild mammals such as deer (probably captured in Margarita island) and rabbits (probably from both Margarita and Cubagua) as well as marine birds from Margarita and the mainland. A few remains of domesticated animals such as pigs, chicken, sheep, goats, and cows have been found, but given their scarcity among the archaeological remains, they were probably brought in to be slaughtered immediately since the lack of natural vegetation in Cubagua did not provide conditions for grazing animals. Some cats and dogs were also introduced (E. Wing 1961). Only pigs and chicken were a bit more common since they are less dependent on natural vegetation to survive and can be fed with human refuse. Some of these animals may have come directly from Spain while others may have come from Hispaniola (E. Reitz 1991, 1992). Again, given the paucity of the records of domesticated 
animals when compared with those of local origin, chances are that the former played only a minor role in the caloric intake of the inhabitants of that short-lived colony. The vegetables eaten at that time included the manioc and the cassava, both being brought from elsewhere in the Caribbean. The ships, in return, took salt from the Araya peninsula.

Even most construction material had to be imported. Masonry was performed by using uncut stones taken from the interior of the island and (mostly) from the Araya peninsula. They were chinked with clay and plastered with lime made by grinding up coral. Clay bricks were used occasionally (I. Rouse and J. Cruxent 1963:135).

Although pearls can still be obtained in the Cubagua waters from natural extraction, the development of the cultivation of pearls around the beginning of the twentieth century (Y. Matsui 1975) made such activity not economically viable.

\section{The Social and Political Impact}

Besides being a pearl production center, Nueva Cádiz served two other functions; it was a collection point for slaving activities on the mainland and a jumping-off spot in the first Spanish attempts at colonizing the South American mainland. The expansion of agricultural practices in the Caribbean, coupled with the rapid extermination of most of the native population of the larger islands by colonists, meant that slaves were in high demand at correspondingly high prices. Nueva Cádiz's location made it a perfect spot to collect captured natives from the mainland to be shipped to buyers in the Greater Antilles. This was possible only because the construction of a fortress in Cumaná in 1523 assured Nueva Cádiz protection from further native uprisings and allowed the colonization of the mainland to begin.

Part of the reason for having slaves had to do with gaining access to pearl beds. To gain that access a person had to be a Señor de Canoa (boat lord), a title of legal stature that was achieved by having at least 12 divers. Iin 1535, some Señores de Canoa may have had up to 50 divers, and the wealthiest in the island had more than one boat (E. Otte 1977:50). As we have seen, the number of slaves and their ethnic origin varied.

The proportion of European to non-Europeans (mostly Native Americans, but also Africans) may have been 1:4 or 1:5 by the height of pearl exploitation. Given the high mortality among slave divers, high demand for cheap slave labor and women, and the low population density along the Venezuelan coast (ca. 50,000 at the time Columbus' arrival; J. Lockhart and S. Schwatrz 1983:283), the local indigenous population was decimated. There was widespread translocation of people, particularly of the Lucayos.

\section{The Ecological Impact}

Although we have reconstructed what happened with the pearl trade in Cubagua based on historical documents, the reconstruction of the depletion of the pearl-oyster beds from an ecological viewpoint is more complicated. The biology of the Caribbean pearl oyster (Pinctada imbricata Röding 1798 [Pteriidae]) is still poorly understood (M. Gervis and N. Sims 1992) and the Spaniards did not leave any useful natural history information. Yet, we can use economic data and what we know of the natural history of this species to infer the magnitude of the exploitation.

Despite careful tax records, estimations of the actual pearl production from Cubagua and adjacent waters have to be conservative if based solely on official records. Contemporary accounts estimate that more than half of the total number of pearls extracted were never declared in order to evade taxes (G. Benzoni 1565; E. Otte 1977:51- 
52). Also, pearls were used as local currency (E. Otte 1977:51-52). Thus, we can safely assume that official records reflect only a fraction of the actual production.

In order to calculate the ecological impact of the pearl fisheries in Cubagua and adjacent areas, we used the most conservatives figures leading to the lowest levels of exploitation. To that end, we used only the official figures of production (summarized by E. Otte 1977) and ignored all speculations regarding undeclared production. Given that the numeric system used at that time was complicated in terms of decimals for equivalencies, we ignored decimals and rounded up numbers to the nearest low integer which, in turn, makes our figures even more conservative. Because official figures represented the 20-percent tax, we multiplied them by 5 in order to obtain the gross production. Of the different estimations of number of pearls obtained by every 1,000 oysters collected, we used the highest productivity or yield per number of oysters collected, as this would also be the most conservative figure from the ecological impact viewpoint. Finally, given that Spanish records rarely contained information about the quantity of pearls but rather about their weight and quality, we assumed that all pearls were of the highest quality and weight (5 carats). In this way, we again used the most conservative approach from the ecological impact viewpoint by assuming the highest possible productivity and the lowest number of oysters extracted per pearl.

\section{Official production figures}

Although we can safely assume that a sizable amount of pearls had been extracted prior to 1515 , we only have detailed records beginning in 1515 . Very precise records for Cubagua began in 1529, when taxation was carried out in situ instead of in Santo Domingo or San Juan de Puerto Rico. Data is summarized in Table 1 and Fig. 3. Based on this, we estimate that total production from Cubagua was, at the minimum, 49,245 marks (11,326.35 kilos), an amount slightly lower than the one calculated by E. Otte (1977:402) given that we did not take decimals into consideration. Since 1 kilo equals 5,000 carats, the total gross production was $56,631,750$ carats.

Although some other species of oyster pearls seem to be more productive in natural conditions, (about 10\% individuals of Pinctada galtsoffi of Hawaii contain pearls, P. Galtsoff 1933), Cubagua's pearls seem to have been rather small in size when compared with other from the Indian and Pacific oceans. They rarely exceeded 20 grains (1 gm) (G. Kunz and C. Stevenson 1908), and they weighed mostly 2, 3, 4, or 5 carats $(0.4,0.6,0.8$, and $1 \mathrm{gm}$, respectively) (G. Benzoni 1565).

The most conservative calculation on pearl productivity is that made by P. Galtsoff (1950:19) who indicates that 200 to 300 oysters are needed to produce only 1 carat $(0.2$ $\mathrm{gm}$ ) of pearls. For the most conservative approximation of 200 oysters per carat of pearls, $11,236,350,000$ oysters would have to be extracted to yield the 56,631,750 carats of gross pearl production. Although we have not been able to find any natural population estimation for this species that would allow us to put this number in context, this figure is astonishing, especially considering the efforts we took to keep these figures as conservative as possible. Therefore, the actual number of oysters harvested can at least be doubled, if we assume that, as contemporary accounts indicate, less than half of the actual production was declared. Further, contemporary records indicate that only one pearl was produced for every 1,000 oysters collected, allowing us to further multiply our calculations by five. In other words, it would not be unreasonable to say that over 100 billion oysters were extracted in less than 30 years. 
Thus, in 1527, when 7,170 marks (1649.1 kilos or 8,245,500 carats) of gross production was declared, at least 1,649,100,000 oysters were harvested. The total human population in Cubagua that year has been estimated at 223 Europeans and 700 natives (E. Otte 1961:xxx). As Europeans were not involved in the actual diving for pearls, each one of the 700 natives would have had to harvest 2,355,857 oysters per year, 196,321 oysters per month, or 7,551 oysters per day (assuming that they were not made to work on Sundays). Given that the natives were made to work from dawn to dusk, that each dive lasted about one minute (M. Helmer 1962), and that each diver's pouch could contain several dozen oysters, that figure does not seem exaggerated.

Further, Rouse and Cruxent (1963:134) estimated that Nueva Cádiz's population reached a maximum of 1,500 residents. This figure suggests that there were more than 1,000 natives and Africans on the island, which makes our calculations even more credible.

How can we translate these production figures into ecological impact? As shallower oyster beds became depleted and divers had to go deeper to obtain pearls, depth complicated the production. Current studies suggest that maximum biomass and density values for Pinctada imbricata occurs at a depth of $8 \mathrm{~m}$ (R. Verginelli and A. Prieto 1991); below that figure, abundance diminishes. The same can be said for growth rate. Although that might result in better quality pearls, as in the case of Pinctada margaritifera (N. Sims 1993), the much lower population density would not compensate in terms of gross production.

Another question is whether Pinctada imbricata had the natural ability to recover after intense exploitation. Although recruitment for this species occurs continuously throughout the year with a maximum in March and minimum in July, its life span is only five years and pearls are not produced until after 4 years of age (R. Verginelli and A. Prieto 1991). It is safe to assume that the Spaniards did not have any knowledge about the life cycle of this species and exploited them all, harvesting many oysters before they could even reproduce. Also, spawning begins late in April and ends late in August. The first moratorium set by the Spaniards (who were ignorant of this aspect of the pearl oyster's biology) took effect in January, which means that, even if these rules were actually enforced, they would have been totally ineffective. Although they eventually extended the prohibition from January to September, this was probably too little too late. These aspects of the biology of this and other species of pearl-producing oysters led us to believe that recovery must have been very difficult, if not impossible, after such intense exploitation.

Finally, even if P. imbricata was able to recover from the reproductive viewpoint, it would have encountered a further obstacle in reestablishing itself in the same area. Both P. imbricata and the turkey-wing mussel (Arca zebra), are suspension-feeding bivalves. They are sympatric in many areas of the Caribbean and are often exposed to the same food resources and environmental conditions. Both species are epifaunal, attaching by bysii to hard substrata in the rocky and shallow sandy shores of sounds, bays, harbors, and lagoons. A. zebra, however, may have a competitive advantage over P. imbricata. The method of intense exploitation practiced by the Spaniards likely generated resuspension of bottom sediments which could have greatly increased the concentration of suspended particulate matter (SPM) and altered the composition of the seston. In many cases, resuspended inorganics reduce the quality of the seston by diluting food particles that are suspended in the water column, such as phytoplankton and particulate organics (J. Ward and B. MacDonald 1996). Under conditions of high levels of SPM, A. zebra shows preferential ingestion of material which lowers the $\mathrm{C}: \mathrm{N}$ ratio and enhances the quality of 
material ingested by an average of 31 percent. That means a physiological compensation for a decrease in food quality. A. zebra has also lower feeding rates than P. imbricata because these two species posses different gill structures which translates into different mechanisms for particle rejection and pseudofeces production (J. Ward and B. MacDonald 1996).

Under conditions of ecological stress generated by overexploitation of one species over the other and a higher concentration of SPM, A. zebra would have been better suited to outcompete $P$. imbricata. By occupying substratum previously covered with $P$. imbricata, A. zebra would have prevented the effective recovery of the pearl oysters. This is a likely scenario given that: (a) several surveys made in Cubagua and adjacent waters in the 1960s showed that almost all of the P. imbricata banks in the region had been completely or almost completely decimated; (b) that $A$. zebra had ecologically replaced $P$. radiata (J. Salaya and L. Salazar 1972), and (c) that there is no evidence whatsoever that A. zebra was ever exploited in significant numbers by the Spaniards. Overfishing for pearls has traditionally been the major factor in the depletion of oyster pearls around the world (M. Cariño Olvera 1995; P. Galtsoff 1932).

\section{Conclusion}

The depletion of pearl-oyster beds at Cubagua and adjacent areas represents the first documented case of a natural resource depletion by Europeans in the American continent. This exploitation was unsustainable from the beginning, primarily because of the intensity of pearl harvesting but also because the Spaniards depended upon a number of other resources (freshwater, wood, food, etc.) that were scarce or absent on that island, and because of the biology of P. imbricata and A. zebra.

TThe Spanish determination to obtain their wealth as rapidly as possible not only led to one of the fastest cases of natural resource depletion in history, but also to severe impacts on the native human population. This impact was affected through increased mortality from harsh living conditions and, probably, by population translocation as all labor used in Cubagua was brought from somewhere else. Yet, there is little evidence that the Spanish received any great benefit from the enterprise, as most of the pearls and other natural riches from the American continent were used to buy manufactured goods in Europe. This is a pattern consistent with similar trades of mineral resources practiced then by the Spaniards (with gold and silver) and now by Venezuelans (oil). In both cases, exploitation of natural resources served only to buy manufactured products instead to develop an intrinsically national-based economy.

Cubagua's example is not unique, and the overexploitation of pearl-oyster beds leading to political, economic, and ecological commotion has been witnessed in varying degrees elsewhere (e.g., Tuamotu Archipelago, in French Polynesia [M. Rapaport 1995]; in Scotland [M. Green 1985-1986]; in India and Sri Lanka [C. de Silva 1978]). But because the colonial powers found well-structured societies in those parts of the world, their impact was not as great as that of the Spaniards in the "Pearls' Coast" of northern South America.

The demand for slaves in pearl-fishing operations had always been significant. As late as the nineteenth century, slaves were taken from Africa for pearl fishing in the Red Sea by the Islamic slave trade (R. Austen 1988). Similar patterns of exploitation of other types of natural resources are still going on in many parts of the world. This is particularly true in less developed nations, where vast amounts of resources are being extracted for the benefit 
of local elites and/or foreign interests in industrialized nations, with little consideration for the environmental impact or the human rights of local people.

Cubagua, therefore, represents a clear example of rapid overexploitation leading toward depletion and/or extinction of species, changes in ecosystem structure, displacement and/or extermination of local human populations and their culture, and disruption of existing economic and political networks. Similar observations have been made for North American natives (D. Bamforth 1994).

Finally, we believe that further studies that go beyond standard academic barriers by looking at environmental problems from an integrative and interdisciplinary viewpoint will generate new insights in resource management and appreciation of many of the ecological problems we face today. This movement towards consilience (sensu Wilson 1998) in environmentally related issues, should produce new and better understanding of the relationships between humans and the environment. This, in turn, may initiate changes in the way conservation biologists are trained today, by urging them to consider more fully the human dimensions of ecological problems, as suggested by Jacobson and McDuff (1998).

\section{Acknowledgments}

Prof. Teresita Martínez-Verne read an early version of the manuscript and made valuable suggestions. Dr. Paul Southgate provided valuable information on oyster biology. Dr. James Mauseth was helpful with the scientific names of plants from Cubagua.

\section{References Cited}

Alexander, C. S.

1958. The Geography of Margarita and Adjacent Islands, Venezuela. University of California Publications in Geography 12:85-192. REFERENCE NOT CITED IN TEXT

Alvard, M. S.

1993 Testing the 'Ecologically Noble Savage' Hypothesis: Interspecific Prey Choice by Piro Hunters of Amazonian Peru. Human Ecology 21:355-387.

1994 Conservation by Native Peoples. Prey Choice in a Depleted Habitat. Human Nature 5:127-154.

1995 Intraspecific Prey Choice by Amazonian Hunters. Current Anthropology 36:789-818.

Anonymous.

1964. Pesca de perlas ilegal en Cubagua (1825). Boletín Histórico (6):39-64. REFERENCE NOT CITED IN TEXT

Anonymous

1970 Léxico Estratigráfico de Venezuela. Boletín de Geología. Publicación Especial No. 4:1-756.

Austen, R.A.

1988 The 19th Century Islamic Slave Trade from East Africa (Swahili and Red Sea Coasts): A Tentative Census. Slavery \& Abolition 9:21-44. 
Bamforth, D. B.

1994 Indigenous People, Indigenous Violence: Precontact Warfare on the North American Plains. Man 29:95-115.

Benzoni, G.

1565 La historia del Mondo Nuovo. Appresso Francesco Rampazetto, Venetia, Italy. Brash, A. R.

1987 The History of Avian Extinction and Forest Conversion on Puerto Rico. Biological Conservation 39:97-111.

Bernabeu, S.

1995 Perlas para la Reina. Aportaciones al estudio de la industria perlífera en la Nueva España (1790-1809). Estudios de Historia Novohispana 15:129-158.

Buege, D. J.

1996 The Ecologically Noble Savage Revisited. Environmental Ethics 18:71-18.

Cariño Olvera, M. M.

1995 La pesca y el cultivo de perlas en la region de La Paz (1870-1940). Su impacto socioeconómico. Siglo XIX: Cuadernos de Historia 2:27-48.

Carlton, J. T.

1993 Neoextinctions of Marine Invertebrates. American Zoologist 33:499-509.

Castellanos, J. de.

1847 [1589] Elegías de Varones ilustres de Indias. M. Rivadeneyra, Madrid, Spain.

Choquenot, D. and D. M. J. S. Bowman

1998 Marsupial Megafauna, Aborigines and the Overkill Hypothesis: Application of Predator-prey Models to the Question of Pleistocene Extinction in Australia. Global Ecology and Biogeography Letters 7:167-180.

Coates, $\mathrm{P}$.

1998 Nature. Western Attitudes since Ancient Times. Berkeley: University of California Press.

Cooke, R.

1998 Human settlement of Central America and Northernmost South America (14,000-8,000 BP). Quaternary International 49/50:177-190.

Defilipps, R. A.

1998 Historical Connections Between the Discovery of Brazil and the Neotropical Brazilwood, Caesalpina echinata Lam. Archives of Natural History 25:103-108.

de Silva, C. R.

1978 The Portuguese and Pearl Fishing off South India and Sri Lanka. South Asia $1: 14-28$.

Diamond, J.

1998 Guns, Germs, and Steel. The Fates of Human Societies. New York: W. W. Norton \& Co.

Forester, D. J. and G. E. Machlis.

1996 Modeling Human Factors That Affect the Loss of Biodiversity. Conservation Biology 10:1253-1263.

Fritts, T. H. and G. H. Rodda.

1998 The Role of Introduced Species in the Degradation of Island Ecosystems: A Case History of Guam. Annual Review of Ecology and Systematics 29:113-140.

Galtsoff, P. S.

1932 The coral reefs of the Hawaiian islands. The Collecting Net 7:29-30. 
Galtsoff, P. S.

1950 Pearl and Hermes Reef, Hawaii, Hydrographical and Biological Observations. Bernice P. Bishop Museum Bulletin 107:3-49.

Galtsoff, P. S.

1950 The Pearl Fishery of Venezuela. Special Scientific Report —Fisheries (26):126.

Gervis, M. H. and N. A. Sims.

1992 The Biology and Culture of Pearl Oysters (Bivalvia: Pteriidae). London: Overseas Development Administration.

Goggin, J.M.

1968. Spanish majolica in the New World. Types of the Sixteenth to Eighteenth centuries. New Haven: Yale University Department of Anthropology.

Green, M.

1985-1986 The history of Scotland's freshwater pearls. British Heritage 7:28-35.

Haring, C. H.

1964 Trade and navigation between Spain and the Indies. Gloucester, MA: Peter Smith.

Headland, T. N.

1997 Revisionism in Ecological Anthropology. Current Anthropology 38:605-630.

Helmer, M

1962 Cubagua, l'ile des perles. Annales 17:751-760.

Hernández Aparicio, P.

1976 La compañía de los Cardona y sus viajes a las pesquerías de perlas de la costa de California. Anuario de Estudios Americanos 33:405-430.

Hulme, $\mathrm{P}$

1986 Colonial Encounters. Europe and the native Caribbean, 1492-1797. London: Methuen.

Humboldt, A. von.

1956 Viaje a las regiones equinocciales del Nuevo Continente. 5 volumes. Caracas, Venezuela: Ministerio de Educación [1799-1804].

Humphries, C. J. and C. T. Fisher.

1994 The Loss of Bank's legacy. Philosophical Transactions of the Royal Society of London B 344:3-9.

Jacobson, S. K. and M. D. McDuff.

1998 Training Idiot Savants: The Lack of Human Dimensions in Conservation Biology. Conservation Biology 12:263-267.

Johnston, J. R.

1909 Flora of the Islands of Margarita and Coche, Venezuela. Contributions from the Grey Herbarium of Harvard University. New Series. (37):163-312.

Kallendorf, $\mathrm{H}$.

1995 A Myth Rejected: The Noble Savage in Dominican Dystopia. Journal of Latin American Studies 27:449-470.

Kicza, J. E.

1992 Patterns in Early Spanish Overseas Expansion. William and Mary Quarterly. Third Series 49:229-253.

Kugler, H.G.

1957 Contribution to the Geology of the Islands Margarita and Cubagua, Venezuela. Bulletin of the Geological Society of America. 68:555-566. 
Kunz, G. F. and C. H. Stevenson.

1908 The Book of The Pearl. New York: The Century Co.

Las Casas, Bartolomé de.

1992 The Devastation of the Indies: A Brief Account [1552]. The Johns HopkinsUniversity Press, Baltimore.

Lockhart, J. \& S. B. Schwartz.

1983 Early Latin America. A History of Colonial Spanish America and Brazil.

Cambridge: Cambridge University Press.

López de Gómara, F.

1965 [1554] Historia General de las Indias. Barcelona, Spain: Editorial Iberia.

Luengo Muñoz, M.

1949 Noticias sobre la fundación de la Ciudad de Nuestra Señora Santa María de los

Remedios, del Cabo de la Vela. Anuario de Estudios Americanos 6:755-798.

Markgraf, V.

1985 Late Pleistocene Faunal Extinctions in Southern Patagonia. Science 228:11101112.

Martin, P. S.

1990 40,000 Years of Extinctions on the "Planet of Doom." Palaeogeography

Palaeoclimatology, Palaeoecology 82:187-201.

1973 The Discovery of America. Science 179:969-974.

Martin, P. S. and C. R. Szuter.

1999 War Zones and Game Sinks in Lewis and Clark's West. Conservation Biology 13:36-45.

Matsui, Y.

1975 On the Origin of Pearl-culture and the History of it in Japan. Proceedings of the 14th International Congress of the History of Science (3):39-42.

McCann, J. M.

1999a Before 1492. The Making of the Pre-Columbian Landscape. Part I: The Environment. Ecological Restoration 17(Spring and Summer):15-30.

McCann, J. M.

1999b Before 1492. The Making of the Pre-Columbian Landscape. Part II: The Vegetation, and Implications for Restoration for 2000 and beyond. Environment. Ecological Restoration 17(Fall):3-15.

McCorkle, T.

1952. The History of the Guayquerí: An Approach to the Anthropology of Northeastern Venezuela. Papers, Kroeber Anthropological Society 6:60-87. REFERENCE NOT IN TEXT

Meine, C.

1999 It's about Time: Conservation Biology and History. Conservation Biology $13: 1-3$.

Miller, G. H.; J. W. Magee, B. J. Johnson, M. L. Fogel, N. A. Spooner, M. T. McCulloch,

L. K. Ayliffe.

1999 Pleistocene Extinction of Genyornis newtoni: Human Impact on Australian Megafauna. Science 283:205-208.

Morón, G.

1954 Los orígenes históricos de Venezuela. I. Introducción al Siglo XVI. Madrid, Spain: Consejo Superior de Investigaciones Científicas. 
Mosk, S. A.

1938. Spanish pearl-fishing operations on the Pearl Coast in the Sixteenth Century.

The Hispanic American Historical Society Review 18:392-400.

Muilenburg, P.

1991. Fate and Fortune on the Pearl Coast. Américas 43:32-39.

O'Connell, J. F. and J. Allen.

1998. When Did Humans First Arrive in Greater Australia and Why is It Important to Know? Evolutionary Anthropology 6:132-146.

Olivo Chacín, B.

1989. Geografía de la Región insular del mar venezolano. Caracas, Venezuela: ArielSeix Barral Venezolana.

Olson, S. L. and H. F. James.

1982 Fossil Birds from the Hawaiian Islands: Evidence for Wholesale Extinction by Man Before Western Contact. Science 217:633-635.

Otte, E.

1977 Las Perlas del Caribe: Nueva Cádiz de Cubagua. Caracas, Venezuela: Fundación John Boulton.

1961 Cedulario de la Monarquía Española Relativo a la Isla de Cubagua (15231550), Tomo I (1523-1534) y Tomo II (1535-1550). Caracas: Fundación John Boulton y Fundación Eugenio Mendoza.

Oviedo Y Valdez, Gonzalo F.

1535 Historia Natural y General de las Indias.

Pastor Bodmer, B.

1992 The Armature of Conquest. Spanish Accounts of the Discovery of America, 1492-1589. Stanford, CA: Stanford University Press.

Pimm, S. L.

1996 Lessons from a kill. Biodiversity Conservation 5:1059-1067.

Pimm, S. L., M. P. Moulton and L. J. Justice.

1994 Bird extinctions in the central Pacific. Philosophical Transactions of the Royal Society of London B 344:27-33.

Ponting, C.

1991 A Green History of the World. The Environment and the Collapse of Great Civilizations. NY: Penguin Books, 432 pp.

Quiévreux, H.

1900 La pêche des perles au Venezuela. La Revue Maritime 146:444-448.

Rapaport, M.

1995 Oysterlust: Islanders, Entrepreneurs, and Colonial Policy over Tuamotu lagoons. Journal of Pacific History [Australia] 30:39-52.

Redford, K. H.

1990 The Ecologically Noble Savage. Cultural Survival Quarterly 15:46-51.

Reitz, E. J.

1991 Dieta y alimentación Hispano-Americana en el Caribe y la Florida en el Siglo XVI. Revista de Indias 51:11-24.

Reitz, E. J.

1992 The Spanish Colonial Experience and Domestic Animals. Historical Archaeology 26:84-91. 
Rodda, G. H., T. H. Fritts and D. Chiszar.

1997 The Disappearance of Guam's Wildlife. New insights for herpetology, evolutionary ecology, and conservation. BioScience 47:565-574.

Romero, A., A. I. Agudo and S. Green.

1997 Exploitation of cetaceans in Venezuela. Reports of the International Whaling Commission 47:735-746.

Rouse, I.

1964. Prehistory of the West Indies. Science 144:499-513.REFERENCE NOT CITED IN TEXT

Rouse, I. and J. M. Cruxent.

1963 Venezuelan Archaeology. New Haven: Yale University Press.

Salaya, J. J. and L. Salazar.

1972 Exploraciones y Explotaciones de la ostra perla (Pinctada imbricata) en Venezuela, 1946-1969. Caracas, Venezuela: Proyecto de Investigación y Desarrollo Pesquero MAC-PNUD- FAO.

Sale, K.

1991 The Conquest of Paradise. Christopher Columbus and the Columbian Legacy. New York: Alfred A. Knop.

Sauer, C. O.

1966 The Early Spanish Main. Berkeley and Los Angeles: University of California Press.

Sherman, W. L.

1979 Forced Native Labor in Sixteenth-Century Central America. Lincoln and London: University of Nebraska Press.

Simmons, I. G.

1993 Environmental History. A Concise Introduction. Oxford, UK: Blackwell.

Simon, J.

1997 Prophecy, plague, and plunder. The Amicus Journal 1997(Spring):28-33.

Simon Velásquez, J.

1956 Petróleo y perlas en Cubagua. Revista Shell, Caracas 5:45-52.

Simpson, L. B.

1950 The Encomienda in New Spain. Berkeley and Los Angeles: University of California Press.

Simpson, L. B.

1970. Los conquistadores y el indio americano. Barcelona, Spain: Ediciones Peninsula.

Sims, N. A.

1993. Size, age and growth of the black-lip pearl oyster, Pinctada margaritifera (L.)

(Bivalvia; Pteriidae). Journal of Shellfish Research 12:223-228.

Stahl, P. W.

1996. Holocene Biodiversity: An Archaeological Perspective from the Americas.

Annual Review of Anthropology 25:105-126.

Steadman, D. W.

1995. Prehistoric Extinctions of Pacific Island Birds: Biodiversity Meets Zooarchaeology. Science 267:1123-1131. 
Steadman, D. W., J. P. White and J. Allen.

1999 Prehistoric Birds from New Ireland, Papua New Guinea: Extinctions on a Large Melanesian Island. Proceedings of the National Academy of Sciences USA 96:2563-2568.

Stiner, M. C., N. D. Munro, T. A. Surovell, E. Tchernov and O. Bar-Yosef.

1999 Paleolithic Population Growth Pulses Evidenced by Small Animal Exploitation. Science 282:190-194.

Stuart, A. J.

1991 Mammalian extinctions in the Later Pleistocene of Northern Eurasia and North America. Biological Reviews 66:453-562.

Tello, J.

1966 Historia del petróleo en Venezuela. El Farol 28(218):6-9.

Verginelli, R. and A. Prieto.

1991 Producción secundaria de Pinctada imbricata (Röding, 1798) (Pterioida: Pteriidae) en una población del Golfo de Cariaco, Venezuela. Acta Científica Venezolana 42:138-144.

Vila, P.

1948 La destrucción de Nueva Cádiz ¿terremoto o huracán? Boletín de la Academia Nacional de la Historia 31(123):213-219.

Ward, J. E. and B. A. MacDonald.

1996 Pre-ingestive Feeding Behaviors of Two Sub-tropical Bivalves (Pinctada imbricata and Arca Zebra): Responses to an Acute Increase in Suspended Sediment Concentration. Bulletin of Marine Science 59:417-432.

Watts, D.

1990 The West Indies: Patterns of Development, Culture and Environmental Change Since 1492. Cambridge: Cambridge University Press.

Webster, D. and G. Webster.

1984 Optimal Hunting and Pleistocene Extinction. Human Ecology 12:275-289.

Williams, E.

1994 [1944] Capitalism \& Slavery. Chapel Hill: The University of Chicago Press.

Willey, G. R.

1971 An Introduction to American Archaeology. Volume Two: South America. Englewood Cliffs, New Jersey: Prentice-Hall, Inc.

Willis, R. F.

1976 The Archeology of 16th Century Nueva Cadiz. Masters Thesis, Gainesville: University of Florida.

Wilson, E.O.

1998 Consilience: The Unity of Knowledge. New York: Alfred A. Knopf, Inc.

Wing, E. S.

1961 Animal Remains Excavated at the Spanish Site of Nueva Cadiz on Cubagua Island of Venezuela. Niewe West-Indische Gids 41:162-165. 


\begin{abstract}
Cubagua's Pearl-Oyster Beds: The First Depletion of a Natural Resource Caused by Europeans in the American Continent

Interdisciplinary approaches to understanding the causes and mechanisms of depletion of natural resources can provide powerful tools in biological conservation policy. We report here what we believe was the first case of a depletion of a natural resource in the American continent by Europeans: the pearl-oyster (Pinctada imbricata) beds off the coast of Cubagua, Venezuela, in the early sixteenth century.

Key words: Pearl-oysters, Depletion, Natural Resources, Overexploitation, Human Rights, Venezuela, Cubagua.
\end{abstract}

\title{
Résumé
}

Les bancs d'huitres de Cubagua: le premier épuisement d'une ressource naturelle causé par les Européens au continent américain.

Une approche interdisciplinaire à la compréhension des causes et des mécanismes de l'épuisement d'une ressource naturelle peut fournir des outils puissants à la politique de conservation biologique. Nous signalons ici ce que nous considérons être le premier cas d'épuisement d'une ressource naturelle causé par les Européens au continent américain: les bancs d'huitres (Pinctada imbricata) sur la côte de Cubagua, Venezuela, au début du seizième siècle.

Mots clefs: huitres à perles, épuisement, ressources naturelles, surexploitation, droits de l'homme, Venezuela, Cubagua.

\section{Resumen}

Las camas de la perla-ostra de Cubagua: El primer agotamiento de un recurso natural causado por los europeos en el continente Americano.

Los enfoques interdisciplinarios para entender las causas y los mecanismos del agotamiento de recursos naturales pueden proporcionar poderosas herramientas en la política de conservación biológica. Señalamos aquí lo que creemos fue el primer caso de un agotamiento de un recurso natural en el continente americano causado por los europeos: las camas de la perla-ostra (imbricata de Pinctada) de la costa de Cubagua, Venezuela, en el Siglo Diecisés.

Palabras claves: Perla-Ostras, Agotamiento, Recursos Naturales, Explotacion excesiva, Derechos Humanos, Venezuela, Cubagua. 